\title{
Review of Scholarship on the Status of African American Faculty Members in English
}

Doug Steward

ADE Bulletin 140 (Fall 2006), pp. 45-60

ISSN: 0001-0898

CrossRef DOI: 10.1632/ade. 140.45

Copyright $@ 2006$ by The Association of Departments of English

All material published by the The Association of Departments of English in any medium is protected by copyright. Users may link to the ADE Web page freely and may quote from ADE publications as allowed by the doctrine of fair use. Written permission is required for any other reproduction of material from any ADE publication.

Send requests for permission to reprint material to the ADE permissions manager by mail (26 Broadway, New York, NY 10004-1789), e-mail (permissions@mla.org), or fax (646 458-0030). 


\title{
Review of Scholarship on the Status of African American Faculty Members in English
}

\author{
DOUG STEWARD
}

\section{Compiled to support} the work of the ADE Ad Hoc Committee on the Status of African American Faculty Members in English, the following scholarship review is not comprehensive. Many other references can be found in the bibliographies of these resources, and research on achieving equity in the makeup of higher education faculties continues apace. Much of the relevant literature treats diversity and equity issues in higher education broadly, a consequence of the difficulty of obtaining reliable data on specific disciplines and the sometimes statistically insignificant numbers when one does. Broad treatments show, too, that the low number of black faculty members in English cannot be attributed to simple, local problems; instead, a complex interaction of social, economic, and educational factors leads black students, especially black men, away from higher education or, more specifically, away from English and militates against their success when they do pursue advanced degrees and faculty careers.

Stephen Cole and Elinor Barber's Increasing Faculty Diversity exemplifies such treatments. With an emphasis on the pipeline leading to elite institutions, Cole and Barber offer detailed analyses of students' high school backgrounds, choice of major, and strategies for promoting academic careers. Their treatment is necessarily broad, however, offering little that is specific to the English discipline; at the same time, its focus on elite institutions limits its relevance to the greater spectrum of higher education institutions. Another broad treatment of special importance is the American Council on Education's annual series of reports Minorities in Higher Education (see Harvey and Anderson), which provides a rich, broad set of data on long-term trends in high school completions, college enrollment rates, degree conferrals at all levels, higher education employment, and presidencies. The series provides valuable current data, set in the context of long-term trends, but does not provide much commentary, interpretation, or strategy. Other sources of general data on minority education are the Woodrow Wilson National Fellowship Foundation's Diversity and the Ph.D. and the National Science Foundation's Web site WebCASPAR: Integrated Science and Engineering Resources Data System. The former includes data, analyses, and recommendations. The latter offers a manipulable Web-based set of national data on higher education completions that extends well beyond science and engineering. Learning to use the data can be difficult; however, the Web site offers unparalleled possibilities for tailoring data to specific disciplines, years, and degree levels and by race and gender.

Broad analyses such as Cole and Barber's and the American Council on Education series are excellent, but they do not offer enough that is specific to English departments' efforts to achieve racial and ethnic equity in hiring. Thus, this review focuses whenever possible on articles and books that identify specific problems and offer practical recommendations for achieving equity in hiring and retention-rather than on the theory, history, or justification of equity measures-especially as such recommendations pertain more narrowly to African Americans, the liberal arts, or English.

The author is associate director of MLA English Programs and the $A D E$.

ADE Bulletin, No. I40, Fall 2006

(C) 2006 BY THE ASSOCIATION OF DEPARTMENTS OF ENGLiSH 


\section{Personal Narratives and Interventions}

Counterbalancing the breadth of such resources are personal narratives that provide individual insight into the experience of black faculty members in English. For instance, in "A Troubled Peace: Black Women in the Halls of the White Academy," Nellie Y. McKay discusses the history and her personal experience of black women in the academy, detailing particular challenges and satisfactions for black women academics. She recounts numerous racially motivated, everyday slights over the years and notes that in a racially biased environment "[n]o skirmish is minor" but is situated in long-standing traditions of white privilege (16). Against the notion that there is a high demand for black scholars, McKay points to the large number of potential black scholars who are prevented, in one way or another, from reaching the job-search stage, and she attributes the low number of African Americans pursuing $\mathrm{PhDs}$ in the arts and sciences, in part, to "admissions policies that fail to keep up with the currents of the times" (21). In "The Staying Power of Racism," Trudier Harris echoes McKay's memories of discriminatory behavior. Anticipating the objection that discrimination must no longer exist since "African American cultural forms saturate our media spaces," Harris argues that the "nonblack American public will tolerate 'blackness' more in the ear than in the eye" (151) in other words, whites tolerate mediated, absent, or invisible blacks but have little tolerance for them in the flesh. Most compelling are Harris's examples of faculty members who, in private, snubbed her while treating her cordially in public settings. Harris is evenhanded and also recounts, in "Black Nerds," the difficulty she faced in the black community as an African American woman pursuing advanced study in English. "Education for the sake of education," she remarks, "was seen as a liability" (101).

While McKay and Harris focus on interactions among faculty members, other articles examine the classroom and job interviews as treacherous sites for young professors of color who are establishing their authority. Rochelle Smith's “Walking on Eggshells: The Experience of a Black Woman Professor" treats student-professor relations. Smith has noticed that white students have a tendency to overgeneralize about black experience on the basis of specific literary works, such as Ralph Ellison's "Battle Royal” or August Wilson's Fences, and in this way "have per- petuated racial stereotypes" (70). She also voices an all-too-common experience of African American professors: "Sometimes students are not as open to my opinions, which they view as biased, because of the barrier erected by racism" (71). For Smith's students, her particularity as a black professor casts doubt on the objectivity that a white professor would presumably exhibit. Susie Lan Cassel's "Pitfalls in Protocols: The Persistence of Race in the Interview Process" provides a compelling account of an Asian American woman's experience in terms that speak readily to other nonmajority members of the profession. Cassel contrasts queer scholars' "closeted vitae and letters" with the ways in which ethnic minorities attempt discreetly to out themselves as such when on the job market, noting that despite her efforts to make her heritage clear, "interviewers made tenacious and persistent requests for racial confirmation" (222-23). Cassel hoped to be judged on the quality of her work and not to be "singled out as a 'token' or as a 'special hire" (225). However, prying and sometimes illegal questions about her background led her to believe that in some cases her heritage was "the single defining question of an interview and thus the single resounding determinant of whether or not [she] would be hired" (227). Despite her efforts to establish appropriate scholarly credentials, overzealous interview tactics left her feeling tokenized.

April Gregory's "Black and Female in the Academy" reprises many of these themes. Gregory recalls, "I was surrounded by colleagues who considered me to be an 'affirmative-action hire' and not a true colleague." Like Cassel and Smith, she found her authority undermined or simply ignored:

\footnotetext{
Not only did I rarely have the opportunity to teach my specialty, but I had to sit back as senior colleagues, who had not formally studied African-American literature in graduate school as I had and who were not particularly welcoming to people of color, were given the opportunity to teach the courses.
}

Gregory recognizes that she had an exceptionally high number of interviews and job offers but adds that racism marred her experiences in and after interviews, leaving her dissatisfied with life "in the academy-a place where sometimes well-intentioned people confuse diversity with tokenism.”

Personal narratives such as these serve at least two vital functions: bearing witness to the experience of other faculty members of color, who may 
sometimes feel as though they are being paranoid, and educating white academics, who may never experience or notice discriminatory behavior or who may be unconscious of their own biased behavior in daily interactions, departmental meetings, and tenure and promotion proceedings.

Other articles bridge the divide between disciplinary theory and the lived reality of black scholars. In sympathy with Harris's "Black Nerds," Cornel West's "The Dilemma of the Black Intellectual" considers the decision to become a black intellectual as "an act of self-imposed marginality" (110) since the black community at large is, in his estimation, suspicious of intellectuals and the white intelligentsia remains profoundly racist. West believes that affirmative action and the managerial ethos of universities cast doubt on young black scholars' qualifications ("confus[ing] diversity with tokenism," in Gregory's phrase), making it more difficult for African Americans to access and thrive in intellectual circles. In addition, the rightward swing of national politics, racial separatism in publishing, and the lack of a sustained institutional tradition of black intellectualism undermine black scholars' place in the academy. Thus, in West's view,

the successful black intellectual capitulates, often uncritically, to the prevailing paradigms and research programmes of the white bourgeois academy, and the "unsuccessful" black intellectual remains encapsulated within the parochial discourses of Afro-American intellectual life.

West therefore urges the adoption of certain dimensions of the bourgeois, Marxist, and Foucauldian traditions in generating a sustainable tradition of black intellectualism that the black sermonic and musical traditions inspire but do not delimit. From the bourgeois, Marxist, and Foucauldian paradigms, black intellectuals should retain, respectively, "the emphasis on human will and heroic effort"; "the stress on structural constraints, class formations, and radical democratic values"; and "the preoccupation with worldly skepticism, the historical constitution of 'regimes of truth,' and the multifarious operations of 'power-knowledge"' (122-23). From the black sermonic and musical traditions, black intellectuals should retain "indigenous institutional practices permeated by the kinetic orality and emotional physicality, the rhythmic syncopation, the protean improvisation, and the religious, rhetorical, and antiphonal rep- etition of Afro-American life" (122). West urges the creation of a sustained tradition of black intellectualism in order to ease African Americans' precarious entry into higher education.

Similarly, in "The Crisis of the Negro Intellectual: A Post-Date," Hortense Spillers laments the dearth of sustained commentary on black intellectuals since Harold Cruse's Crisis of the Negro Intellectual in 1967. She recalls her excitement at discovering that work's "auto-bios-graphē in the perspective of historical time and agency" and explores "what the problem is that constitutes a 'crisis' for the African American creative intellectual at the moment" (67). She points to the contradiction in both blaming (black) intellectuals for social ills and attributing to them no social agency. Whereas West calls for a tradition of method in black intellectualism, Spillers calls for a renewed interrogation of what black intellectuals should take as their object of study. She writes:

To my mind, that object must move through a first step-to become a disciplinary object, or to undergo transformation of African American studies into an "object of knowledge," rather than a more or less elaborate repertory of performative gestures and utterances.

In Spiller's view, racist hiring practices and the commercialization-commodification of black studies have militated against the long-term and widespread development of that disciplinary object. Unlike West and Harris, who remark on the black intellectual's uneasy relation to the black community, Spillers writes that the black intellectual "brings the community with him to [his laboratory], bears it between his ears, so that, quite remarkably his community must be rethought on the site of the foreign, with the learned tool" (115). Both West and Spillers seek disciplinary means (method and object) to secure African Americans' place in the academy, and both draw on black traditions to do so.

West and Spillers are not alone in turning attention to African American faculty members' relation to the black community. In "A New Chair's Perspectives, White and Black, of English Studies," Robert Ochsner recalls his experience as a white department chair of moving from a predominantly white to a predominantly black institution, noting that the faculty of the English department at the Historically Black University, Fayetteville State University, was the only one at the institution that was predominantly white. Ochsner underscores 
an important consequence of this anomaly in the department's racial makeup:

Many students and some faculty members regard[ed] the major program in English as basically intended for white people in its celebration of white culture. If this attitude is shared by minority students at other schools, ... then addressing it becomes an important responsibility of English teachers everywhere.

\section{Moreover, echoing Harris, Ochsner believes:}

The assumption that English majors can obtain only teaching jobs further complicates the reaction of many blacks to studying English. ... English studies (white studies) is regarded as an easier major for white students-or as the major for blacks who aspire to become white. Graduate programs in English are considered the pastime of privileged, wealthy white people who do not need to worry about job opportunities or tests that discriminate against most blacks.

To counter these image problems, Ochsner recommends changes in doctoral programs to ensure that new curricula are taught by a diverse faculty with the ability to attract a diverse student body. Based on his time at Fayetteville, Ochsner concludes that "[t]he white faculty [at a historically white institution] is less attuned to the political concerns of black colleagues, who understand the politics of language as people who have successfully mastered the language of power" (23).

In "Intellectuals and the Persisting Significance of Race," William M. Banks and Joseph Jewell provide a broader, less personal account of African American faculty members' experience of the academy and of the black community. Beginning with a review of the literature on whether black intellectuals do and should maintain a strong "ethnic" element as intellectuals, this survey of 184 black thinkers indicates that while most respondents (75\%) believed intellectuals are alienated from nonintellectuals, they themselves (65\%) did not feel alienated. Sixty-seven percent "described themselves as 'very' or 'moderately' active in African American community organizations" (81). Ninety percent of respondents felt that they carried a commitment to their ethnicity into their intellectual work but also that they encountered resistance when specializing in areas outside African American studies. To the extent that black intellectuals assume

a responsibility to reflect or address the interest of Blacks in their work[,] ... African American intellectuals di- verge dramatically from the prototype of the intellectual community as a subsociety bound by a commitment to abstract ideals and universalistic values that transcend the social origins of individual members.

(82-83)

Although the research of Banks and Jewell shows black intellectuals do not feel alienated from the black community, they quote Cornel West describing African American intellectuals as "[c]aught between an insolent American society and insouciant Black community" (83 [West 109]). Banks and Jewell's most useful point might be that " $[w]$ hen, in the face of constraints and pressure, Black intellectuals particularize their interests and energies, they deviate from one of the governing tenets of Western intellectual life" (84). This tension between particular (subjective) and universal (objective) may shed light on why some white administrators view specifically African American scholarship with suspicion.

\section{From the Pipeline to Paths}

Among the factors contributing to the dearth of black faculty members, the pipeline has perhaps occasioned the most comment. But the pipeline cannot be considered the only factor, and too often comment on it amounts to an excuse for not hiring more African American faculty members. With a shrug and a sigh, department chairs note that there simply aren't enough black candidates coming through the pipeline and consider the question closed and beyond their control. The most useful literature on the pipeline takes a different tack: in Robyn Warhol's words, "extraordinary results sometimes require extraordinary efforts" (58).

A backward glance at William Moore, Jr., and Lonnie H. Wagstaff's Black Educators in White Colleges (1974) illustrates that the pipeline issue has changed little in more than thirty years: administrators excuse the lack of diversity in the faculty by pointing to the dry pipeline (despite accounts of black PhDs unable to find jobs) or by claiming that black $\mathrm{PhDs}$ are too expensive (despite the authors' statistics showing that black PhDs do not make more than white PhDs). The work of Moore and Wagstaff provides a rich picture of black educators' attitudes in 1974, thanks to a survey to which over three thousand black faculty members and administrators responded. 
More recently, Cole and Barber argue, with an emphasis on elite institutions, that the low number of high-achieving undergraduates of color, particularly among African Americans, who choose to pursue PhDs is in fact the primary source of the underrepresentation of faculty of color. Not content merely to establish the validity of the pipeline problem, Cole and Barber review research on how students choose certain majors, showing that students' choice of an academic occupation can be correlated with high precollegiate academic preparation and superior college achievement and discounting a correlation with a number of other possible factors. To increase the interest of undergraduates of color in obtaining a $\mathrm{PhD}$, they recommend policy changes at elite and all four-year institutions. They urge elite institutions to ask incoming students about their likely career choice; to follow up with those interested in academia; and to "give preference to African American ... applicants who are interested in academia over those who express an interest in medicine," a field in which African Americans are overrepresented at elite schools (241). They urge all institutions to "appoint a staff member whose primary responsibility is to serve as an advisor to students who are interested in careers as professors" (242); to set up programs to foster interest in academic careers among students of color; to prepare materials that present a realistic but positive picture of what life as a professor is like, as well as present its possible advantages over other careers; to foster contact between faculty members (including academic alumni) and undergraduate students and between graduate and undergraduate students that informs undergraduates about faculty and graduate life; and to improve academic performance of students of color through selection of an undergraduate institution appropriate to the student's high school preparation, minimization of stereotype vulnerability, tutoring (especially in science), counteraction of possible cultural suspicion of academic achievement, and involvement in teaching and research opportunities. Although Cole and Barber's background at and focus on elite institutions at times undermine their work's wider usefulness, their comprehensive response to the pipeline is exemplary. They understand the shortage of African Americans coming up through the educational system and into graduate programs leading to academic careers not as the reason there are too few black academics but as a problem to be redressed through various means.

Other articles addressing the pipeline are "Striking the Delicate Balances," by Mamie E. Locke, which looks more specifically at black women, and "Exploring Underrepresentation: The Case of Faculty of Color in the Midwest," by Caroline Sotello Viernes Turner, Samuel L. Myers, Jr., and John W. Creswell, which remarks that " $\mathrm{t}]$ here seem to be increasing numbers of African Americans entering the higher education pipeline" but "fewer who are leaving it with advanced degrees" (37).

Most recently, Clifford Adelman's substantial study The Toolbox Revisited, sponsored by the United States Department of Education, addresses "completion of academic credentials - the culmination of opportunity, guidance, choice, effort, and commitment" and finds that " $\mathrm{t}]$ he academic intensity of the student's high school curriculum still counts more than anything else in precollegiate history in providing momentum toward completing a bachelor's degree" (xv, xviii). Finding, too, that only socioeconomic status-not gender, race, or ethnicity- "was significantly associated with degree completion,” the report suggests that the less rigorous high school curricula offered to underprivileged students contributes more to those students' lack of success in higher education than does race or ethnicity per se. Toolbox explores precisely which measures correlate with higher rates of higher education degree completion for students of color, takes these measures as the basis for projected completion rates if the measures were widely used, and presents its conclusions in table 32. Adelman summarizes the findings:

For African-American students, who start out at a higher bachelor's degree completion rate than do Latinos, the high school academic curriculum factor does not close the degree completion gap by a statistically significant amount, but earning more than four credits in summer terms offers a stunning boost, narrowing the completion gap vis-à-vis white students from 15.5 percent to 6 percent. The momentum provided by this high-octane persistence behavior continues through the first calendar year credits criterion and avoidance of no-penalty withdrawals and no-credit repeat grades until, at the bottom line of the hypothetical rates set forth in table 32, African-American degree completion rates would be no different from those of whites and Asians. . . Point out to AfricanAmerican students that their peers have proved (a) summer-term credit production is a benefit, and (b) the student can concentrate in the summer terms 
Table 32 (Adelman, Toolbox 92)

Hypothetical Cumulative Consequences of Variables Critical to Bachelor's Degree Completion for 1992 12th-Graders Who Earned a Standard High School Diploma by December 1996, Attended a Four-Year College at Any Time, and Whose Postsecondary Records Were Complete, by Race/Ethnicity

\begin{tabular}{|c|c|c|c|c|c|}
\hline \multirow[b]{2}{*}{ Cumulative Conditions } & \multicolumn{5}{|c|}{ Percentage Earning Bachelor's Degree } \\
\hline & White & $\begin{array}{c}\text { African } \\
\text { American }\end{array}$ & Latino & Asian & All \\
\hline 1. Baseline, no conditions & $67.6(1.18)$ & $52.1(4.26)$ & $45.4(3.74)$ & $67.9(4.71)$ & $64.6(1.12)$ \\
\hline 2. No delay of entry & $71.0(1.22)$ & $54.6(4.49)$ & $50.5(3.79)$ & $68.2(4.89)$ & $67.9(1.15)$ \\
\hline $\begin{array}{l}\text { 3. No delay, top } 40 \% \text { of high school } \\
\text { curriculum, and highest high school } \\
\text { mathematics above Algebra } 2\end{array}$ & $85.6(1.50)$ & $65.9(8.57)$ & $69.2(6.33)$ & $91.5(1.96)$ & $84.1(1.40)$ \\
\hline $\begin{array}{l}\text { 4. No delay, top } 40 \% \text { of high school } \\
\text { curriculum, and more than four credits in } \\
\text { summer terms }\end{array}$ & $90.6(1.31)$ & $84.6(5.95)$ & $69.2(8.12)$ & $92.6(2.27)$ & $89.1(1.30)$ \\
\hline $\begin{array}{l}\text { 5. No delay, top } 40 \% \text { of high school } \\
\text { curriculum, more than four credits in } \\
\text { summer terms, and } 20 \text { or more credits in } \\
\text { first calendar year of attendance }\end{array}$ & $92.6(1.23)$ & $88.2(5.28)$ & $71.9(9.07)$ & $93.9(2.16)$ & $91.4(1.24)$ \\
\hline $\begin{array}{l}\text { 6. No delay, top } 40 \% \text { of high school curriculum, } \\
\text { more than four credits in summer terms, } \\
20 \text { or more credits in first calendar year of } \\
\text { attendance, and less than } 10 \% \text { of grades were } \\
\text { withdrawals or no-credits repeats }\end{array}$ & $95.5(0.98)$ & $94.3(4.62)$ & $79.4(11.10)$ & $95.3(2.20)$ & $94.6(1.07)$ \\
\hline
\end{tabular}

Notes: Standard errors in parentheses. Weighted Ns for each cumulative step: (1) 1.45M; (2) 1.33M; (3) 712k; (4) 621k; (5) $310 \mathrm{k} ;(6) 273 \mathrm{k}$

Source: National Center for Educational Statistics: NELS: 88/2000 Postsecondary Transcripts Files (NCES 2003-402).

on the kind of critically demanding and critical gateway courses that might not otherwise be in as intense focus during an academic year term. The learning goes deeper under single-subject concentration. Examples include organic chemistry, calculus, and experimental psychology.

(93-94)

Such recommendations merit strong consideration, especially in the light of other studies that have recommended summer programs for African American students (e.g., see Jacobson).

In Toolbox and in "Diversity: Walk the Walk, and Drop the Talk," Adelman urges attention to the language used to discuss minority students' achievement in higher education, since "[1]anguage does more than reflect reality-it creates reality as well" (Toolbox 106). Noting that much of the language that institutions of higher education use deprives students of agency, Adelman recommends "persistence" rather than "retention" or "attrition" and "paths" rather than "pipeline" (107) — language that attributes agency to students. In "Diversity," he excoriates administrative mumbo jumbo about "diversity" and rec- ommends instead a franker promotion of "equity." The article details important differences in black students' views on diversity and administrative uses of the term, which can put a misleading spin on the reality of low access and completion rates for students of color. The article also provides data that "cut through fog" (40) to see what would really equalize opportunity for students of color. Adelman urges:

\footnotetext{
If we are genuinely interested in degree completion for minority students, we have to help them acquire more of the resources that enhance their chances: an academic curriculum of high intensity and of a quality that inevitably will be reflected in third-party assessments.

He advocates that colleges double the number of precollegiate outreach programs, especially among community colleges; quadruple the number of faculty members involved in outreach; involve underrepresented students in outreach programs while they are in middle school; include ESL for students' family members where the home language is not English; emphasize reading skills; and make 
preparatory learning the first priority and cultural expression and talent development the second. Although it is not based on the detailed research and data of Toolbox, this brief, accessible article should be on the short list of recommended reading for improving minority students' pathways to and through higher education.

In Faculty Diversity: Problems and Strategies, JoAnn Moody dissents from the pipeline view, rejecting the idea that the root difficulty of hiring faculty of color is "an undersupply of job candidates with doctorates." It is instead, she argues, "unconscionably high barriers to minorities' entry into and success in the professoriate" (1). Moody does not disprove analyses of the pipeline, such as that by Cole and Barber. But she focuses instead on what can be done to support the success of those African Americans who do make it to the job market (there are plenty of them out there, she suggests). In this regard, her article "Supporting Women and Minority Faculty" offers a succinct list of strategies that is perhaps more useful than her sometimes long-winded and needlessly polemical book. The list merits consideration: (1) Thoroughly prepare new hires for their duties. They should be informed about the department's expectations, its type of students, and the equipment or support they should expect. Ensure that the department understands the value of the hire's work and that the hire receives good mentoring. (2) Introduce hires in a way that welcomes them and assures others of their authority to be there. (3) Provide regular first-year orientation meetings that educate hires about all aspects of the institution. (4) Inform hires of all requirements for tenure and what the requirements mean. (5) Introduce hires to colleagues and other networks and persist in such introductions. Ask the hires for their advice. (6) Assign trained mentors to new hires. (7) Protect new hires from too much teaching, advising, or service. Beware of efforts to tokenize them. (8) Assess pretenure faculty members and keep them updated on how they're doing. (9) Monitor tenure-and-promotion reviews and correct errors or misconceptions. (10) Promote women and minorities as leaders and prevent their being undervalued.

Helpful as Moody's list of support strategies is, it cannot serve as a substitute for the more difficult work of increasing the number of African American students coming through the pipeline.

\section{Problems in Hiring and Retention}

The weight of evidence contradicts Moody's claim that there are adequate numbers of African Americans on the path to academic careers, therefore search committees may have difficulty finding black candidates. Several commentators argue that higher education's economy of prestige impedes search committees' ability to locate or recognize qualified black candidates. Locke understands this problem as search committees' desire to find "the African American 'superstar' in their recruitment efforts" (342-43), a dimension of the way black scholars are held to higher standards than other faculty members. Dolan Hubbard, in "Democratizing the Academy," and Walter R. Allen, Edgar G. Epps, Elizabeth A. Guillory, Susan A. Suh, and Marguerite Bonous-Hammarth, in "The Black Academic: Faculty Status among African Americans in U.S. Higher Education," argue that long-standing inequalities in the education available to African Americans place black students and job candidates at a disadvantage. Hubbard questions the implications of assessment and the "university of excellence" for students of color and urges against the reduction of student worth to assessment test scores, since such a reduction obscures the issues of access and equity and tends to secure existing class privilege. Similarly, Allen and his coauthors analyze how "the academic prestige hierarchy contributes to the maintenance of substantial education inequality.” Describing a kind of self-perpetuating cycle, the authors write:

The prestige rankings of the institutions where individ-
uals earn doctoral degrees often determine the prestige
of the institutions where they obtain employment. . .
Further, the low representation of African American
students at prestigious undergraduate institutions leads
to their low representation at highly prestigious gradu-
ate schools.

The authors conclude that "African American faculty members are less often tenured, earn less, work at less prestigious institutions, have lower academic rank, and have less academic stature compared to their White peers" (125). The pattern then repeats itself in the next generation of black scholars.

Such an account of prestige's influence sits ill with a society accustomed to thinking of itself as merit-based. In "The Demographic Fallacy of the Black Academic: Does Quality Rise to the Top?," 
Roslyn Arlin Mickelson and Melvin L. Oliver explore the extent to which prestige rather than qualifications influences black scholars' job prospects. They argue that search committees' erroneous assumption-fueled by the desire for institutional prestige - that the best candidates will come from the universities with the most prestige aggravates the underrepresentation of black faculty. They suggest that committees may decline to consider any candidates from less prestigious institutions, thereby overlooking qualified black candidates. The authors consider meritocracy a sham and point out that the prestige of big-name institutions maintains its power not through legitimate merit but because consensus does not exist on what is meritorious in the profession:

The power of institutional reputation (and likewise departmental reputation) is made all the more important by the inability of faculty and selection committees to agree upon the factors that constitute "excellence in research and teaching."

Lacking initial privilege, black students suffer from a system that meretriciously assumes measurements of merit will ensure that the best applicants move up at each stage. The authors conclude by turning to data from the National Study of Black College Students that suggest that black candidates from less prestigious institutions are not less qualified than black candidates from the most prestigious.

Jerlando F. L. Jackson and James L. Moore III introduce a special issue of Teachers College Record on black men's progress in higher education's pipeline with a discussion of how widespread descriptions of black men as "endangered, uneducable, dysfunctional, and dangerous . . . can negatively impact the perceived ability and subsequent behavior of African American males" (201). Jackson and Moore's discussion echoes Claude M. Steele's well-known study "A Threat in the Air: How Stereotypes Shape Intellectual Identity and Performance," which argues that "stereotype threat" undermines black students' ability to achieve their potential. Among the articles that Jackson and Moore introduce, one finds that "authoritative parenting and positive racial socialization" contribute to black males' success in higher education, another finds that black male students at four-year institutions "reported higher levels of academic and social integration within the first year" than those at two-year institutions $(202,203)$.
Also emphasizing the importance of socialization in educational environments, Edward Taylor and James Soto Antony draw directly on Steele's work in "Stereotype Threat Reduction and Wise Schooling: Towards the Successful Socialization of African American Doctoral Students in Education." They conclude that effective strategies to reduce the threat of stereotypes include:

(a) optimistic teacher/student relationships, where teachers make their confidence in students explicit; (b) challenging, rather than remedial[,] expectations and academic work, which builds on promise and potential, not failure; (c) stress on the expandability of intelligence, that skills can be learned and extended through education and experience[;] (d) affirmation of intellectual belongingness; (e) emphasis on the value of multiple perspectives; and (f) the presence of role models of people who have successfully overcome stereotype threat.

(187)

The authors also found that the doctoral students in education whom they interviewed understood their research and service as intimately tied, in contrast to their professors, who more typically understood them as discrete activities.

Once employed in a faculty position, professors of color face a host of stress factors that may weaken their ability to succeed. Turner, Myers, and Creswell list such sources of anxiety: informal isolation and lack of mentoring in the department; heavy service loads; devaluation of research on minority issues (often published in nonmainstream journals); misconceptions that they are less-qualified, token hires; racial or ethnic bias in tenure and promotion (30-32); and a "chilly climate." Under this last heading are

being denied or overlooked for the tenure and promotion process, being held to standards higher than those for white faculty, having color be more important than credentials, being a "token" faculty member, being expected to handle minority affairs, and, overall, needing more faculty of color on staff.

Black faculty members in their study particularly noted "being both hypervisible and invisible" as a source of frustration and psychological fatigue (44). Carolyn J. Thompson and Eric L. Dey complement such findings in "Pushed to the Margins: Sources of Stress for African American College and University Faculty," which reports the results of an eighteenitem survey, broken down by institutional type and gender. Thompson and Dey suggest that potential 
black faculty members may be discouraged by the types of stress they are subject to. They find that the three most common areas of discouragement are promotion concerns (except at two-year colleges), time constraints, and overall stress. Having research interests and being sexually harassed serve as predictors for all three types of stress.

Many other commentators take up one or another of the stress factors treated generally by Thompson and Dey and by Turner, Myers, and Creswell. Fred A. Bonner's "Black Professors: On the Track but out of the Loop" helpfully lists the daily irritations that African American members of the faculty may encounter: proving oneself over and over, being expected to provide entertainment, being kept out of the loop of professional networks, playing two roles (black and academic), and feeling unwelcome or only tolerated. In "So Many Committees, So Little Time," Piper Fogg looks more specifically at the greater service expectations placed on minority faculty members. Fogg writes:

\begin{abstract}
Some education experts, noting that female and $\mathrm{mi-}$ nority professors shoulder a larger service burden than their peers, warn that this tendency [to expect greater service commitments] may be hampering their move up the career ladder. . . . Personal satisfaction aside, many professors complain that performing a lot of service does not get enough credit in academe.
\end{abstract}

Nevertheless, Fogg reports that, according to Barbara Keating, faculty members of color may feel obligated to undertake committee service, since "[m]any issues that are important to women or minorities won't get attention unless those same groups volunteer to work on them.” A similar motive may tempt African American professors to take on too many advising responsibilities as well, if they fear that students of color will not be served well by other faculty members.

Banks and Jewell underscore a further irritant to some black scholars: the assumption that the scholars specialize in black subjects. As Banks and Jewell put it:

The past and present racial matrix in intellectual institutions and the broader culture in the United States has created a situation in which White Americans expect African American intellectuals to be authorities on all matters involving Black people. Whereas it is unlikely that Whites would turn, for example, to a third-generation Irish American biologist to provide knowledgeable commentary about Irish politics, almost any Black scholar-be he or she a biologist, physicist, historian, or zoologist-can relate an instance when he or she was expected by Whites to be an expert on U.S. racial issues.

Banks and Jewell find that the academy may judge black scholars who carry a commitment to the black community into their work as failing to adhere to academic ideals of abstraction and universality. Thus, pressuring black scholars to work in African American studies effectively pressures them to work in an area that the academy suspects of lacking requisite rigor and objectivity.

The Journal of Blacks in Higher Education highlights the issue of containing black scholars in African American studies in "Black Historians Who Don't Concentrate in the Field of AfricanAmerican History," noting, "When AfricanAmerican faculty members are engaged in the social sciences or the humanities they almost always teach courses relating to the problems of black people." The Journal considers such hiring practices damaging, since "[c]olleges and universities that have increased overall minority hiring totals by engaging blacks to teach African-American studies courses feel less pressure to hire [black scholars] in other departments within the institution." The damage may be personal as well as institutional. Says one black historian of medieval European history:

I got the "what are you doing studying their history"
reactions from other black people ... [but some black
colleagues] tell me my success in a nonblack field en-
hances the value of their work, since I demonstrate that
blacks are intellectually capable of successful academic
pursuits in any field.

The Journal concludes that "an institutional demand bias strongly favors those [black scholars] who choose to work within the limits set by the bias." Naturally, black scholars will not feel the same kind of pressure and bias at Historically Black Colleges and Universities (HBCUs), where African American members of the faculty regularly work in every field.

A handful of studies suggest that faculty members of color receive lower student evaluation scores than white members of the faculty, an issue on which the MLA Committee on the Literatures of People of Color has expressed particular concern. In "Students' Perceptions of Professors: Benefits and Barriers according to Ethnicity and Gender," Kristin J. Anderson and Gabriel Smith note: 
There is a body of research on students' judgments of women faculty, but few studies have examined students' perceptions and judgments of ethnic minority faculty. Even fewer studies have addressed the interaction of such perceptions with course content and the impact of these perceptions on student evaluation of instruction.

A comparison of evaluations of white and Latino professors, their study found that

ratings of professor warmth and availability for Latino professors appear to be contingent on their teaching style, whereas the rating of Anglo professors' warmth is less contingent on teaching style. ... Among women professors with strict teaching styles, Anglo women were rated as more capable than Latinas with the same teaching style. . . . Lenient Latinas were viewed as more capable than strict Latinas, whereas Anglo professors' capability was not contingent on teaching style... . Although Latino and women professors appear not to be rated negatively solely on the basis of ethnicity and gender, prejudiced students may have felt justified in expressing negative feelings toward a Latino professor, for example, under the conviction that they disliked her or his teaching style.

(196-97)

Similar dynamics could be at work in African American professors' classrooms, but as Roxanna Harlow notes, information remains anecdotal and few commentators have really studied the classroom as an emotional space. Harlow's study documents that black professors are reluctant to attribute racism to their students when asked about it in general terms. When asked more specific questions, however,

76 percent of the black professors reported that students questioned their competency, qualifications, and credibility. ... In essence, most black professors felt that their classes always contained at least some students who questioned their right to hold the status of professor.

Black assistant professors, in particular, "reported that students resisted their intellectual authority." By contrast, some white male professors "downplayed their intellectual presence in order to seem more approachable to students" (352), and white professors did not typically worry about whether or not their students had confidence in them and gave little thought to how their race might shape student attitudes toward them. In Harlow's study, many of the African American professors, especially the women, adopted "a strict, authoritative demeanor" in order to establish the authority that students did not automatically grant them as professors (354). (A high percentage of white women professors also described their teaching style as strict and authoritative, but few white men did.) While race might enhance a professor's authority in a course on race, it also detracted from

students' perceptions of their intellectual knowledge of the material: that is, the scholarly, "objective," assessment of racial issues. . . Adding to the professors' frustration was the fact that both white and nonwhite students doubted their academic abilities.

(359)

Pressure to establish authority with students and colleagues also led many black professors "to be perfect for the whole race because people might interpret any negative personal performance as a reflection on African Americans overall" (355-56). Stereotypes about women led both white and black women to "avoid being seen as mean or cold, [but] black female faculty members were more likely to report actual evaluations by students as mean, cold, or intimidating” (357). Harlow concludes: "White professors operate in a social space where whiteness is crediting and privileged, but is invisible and thus is taken for granted; African American professors function in a space where blackness is discrediting and devalued" (362).

Unlike Harlow's study, which relied on professors' reports of their interaction with students, in "Student Perceptions of the Influence of Race on Professor Credibility" Katherine Hendrix examines students' views. She found that students "admitted they assigned more credibility to Blacks teaching 'ethnic' courses or believed other students - in particular, Whites-would do so" and that "Black professors had to work harder to establish their credibility," particularly when the course content was unrelated to African Americans $(749,750)$. Both white and black students reported struggling with negative stereotypes about African American professors. Hendrix's findings, while based on a small number of cases, generally support Harlow's.

\section{Solutions}

Many commentators emphasize the importance of improving African Americans' English education in an articulated fashion from high school 
through the undergraduate years and of promoting awareness of academic careers and English in particular in the African American community. In John Maguire's words, "It is hard to overestimate the role that language plays in the education of minority students and how quickly those showing difficulty with English get shunted into the lower tracks and remain there" (29). Commentators also call for a greater role for fellowships, research and study-abroad opportunities, and summer programs - "the whole set of programs," in Ann Bradford Warner's words, "that help young students think about teaching and graduate school." In a conversation among professors at HBCUs, Warner alludes to the prominence of secondary education as a career choice among black students and observes that her department has

sent many people into $\mathrm{PhD}$ programs who thought at first they would go into secondary education. If they see, as first-year or second-year students, their future in a graduate program, then their design of their courses, the plans for study abroad, the way in which these students will be equipped to apply will change the access to graduate schools. But it takes good recruitment from graduate programs, recruiters even coming to specific schools and communicating what kind of curriculum they're looking for, bringing students of color in to talk about the nature of the community and the nature of the experience so that students who are undergraduates can shape a new idea of their future. ("Fostering" 33)

James J. Davis points in the same conversation to the need for "reeducation in the black community ... we have to start in homes and say, 'It's OK for the child to stay in school for twelve years. We need this [student to pursue graduate work] to supply a demand that we have here" ("Fostering" 34). Among other steps, Davis recommends changing modern language departments' names to reflect the range of their activities and counteract the impression that all they do is grammar and conjugation. Warner also notes that her department changed its curriculum to fit better with the expectations of graduate departments to which its students might apply. She urges:

If graduate recruiters can find the time and way to pay attention, especially to departments in places that may be a little neglected, there can be a tremendous response, because there are stars everywhere, and these kids, maybe they're candles and they just need to be lit a little bit in time to see themselves in a new way.

("Fostering" 36)
In "Recruiting and Retaining African American Graduate Students," Warner provides complementary suggestions, advocating recruitment through funding and active faculty participation, flexible curricula that include interdisciplinary work, community building in academic programs and in the geographic region, and advising and mentoring from undergraduate years through the tenure process. Among the effective strategies that Turner, Myers, and Creswell list are fellowships designed to increase the number of $\mathrm{PhD}$ candidates of color, hiring programs that provide doctoral support for candidates who are guaranteed a tenure-track job after graduation, and mentoring and network programs. Faculty members of color in their study reported a commitment to stay in academia when they had networking opportunities, good mentors, and institutional support for research and publication. In "Coping with the Unexpected: Black Faculty at Predominantly White Institutions," Bonita K. Butner, Hansel Burley, and Aretha F. Marbley make similar recommendations, with a focus on mentoring, professionalization, and a sense of belonging. Lacking senior colleagues who could mentor them in their areas, the authors collaborated with one another, meeting once a month off-campus to discuss their research. They note, "Informal interaction [with the range of an institution's faculty members] is crucial in understanding and traversing the unwritten rules of the institution and the tenure process" (458). They caution against too much institutional service, recommend participation in institution-wide mentoring and governance opportunities to develop collegial relations, and list the several community organizations they participated in to retain a connection with the black community and sustain their spirits.

The report of the Woodrow Wilson National Fellowship Foundation recommends the establishment of a national clearinghouse to share information on minority-focused fellowships. It also recommends the generation of strategies for vertical integration that draws students of color up from $\mathrm{K}-12$ through doctoral programs, habitual practices that promote an image of doctoral education that is "less abstract and more socially responsive in a non-reductive way" (5), mentoring and professionalizing experiences that encourage minority students' participation, consideration of race and need together, and federal leadership to support federal mandates. Common to these various sources are advocacy for socially relevant curricula and a concern to keep students on 
the path toward graduate education through proven strategies such as summer programs and fellowship opportunities directed at students of color.

Hiring searches rank among the most emotionally fraught moments in African Americans' path to the profession, and such moments are laden with unspoken assumptions on the part of hiring committees, candidates, departments, and administrators about the relation between hiring individuals and hiring for particular positions. On the one hand are damaging assumptions about the value of African American studies, African American job candidates, and what qualifies a candidate to teach a particular subject. On the other hand are the numerous practices that departments can use or avoid in order to attract black candidates for the positions they advertise. It should go without saying that black candidates may be qualified to teach in any area of English studies. Unfortunately, many departments continue to assume that black candidates will teach black literature. As McKay writes in "Naming the Problem," "African American scholars seeking appointments in more-traditional fields [than black studies] for which they were trained confront an automatic assumption that they are better able to teach, say, Morrison than Milton." The inverse of the problem is "scholarship in African American literature by white scholars who, without training in the area, assume authority [in it]" (365). Whether the field is assumed available to scholars who have not undertaken the kind of work assumed necessary in other fields or a scholar is assumed qualified only to work in a minority area, field and scholar are diminished.

McKay urges departments to consider African American literature a field like any other, in which scholarly credentials qualify one to teach, and to resist the notion that a position in black literature is the only opportunity to hire a black scholar. Emphasizing the importance of the field itself, she writes:

Too often one sees the same position [in African American literature] advertised and readvertised from one year to the next, while the most-qualified nonblack candidates are turned away, important work is left undone, and the crisis is allowed to continue unabated. ... The alternative to having a black professor of African American literature should not be not having a professor of African American literature. (364-65)

The department chairs Dennis Baron and Robyn Warhol have both made similar arguments against conflating job candidates' ethnicity with qualifications for a position in African American literature. Admitting that there is an expectation from ethnic studies programs, students, and some faculty members and administrators "that minority studies will be taught by professors of color," Baron rejects such thinking; points to the faculty members and graduate students in his department who do not "match" the subjects they study; and argues that the best thing for candidates, the department, and the fields in question is to hire the most qualified candidates. From another perspective, Warhol cautions:

If a department runs a search in African American
literature with the goal of both increasing course of-
ferings in the field and adding a minority PhD to the
faculty, chances are that the search will yield only white
finalists. Rather than fold the search, such departments
should go ahead and hire the white faculty member
who specializes in African American studies and sup-
port that professor's efforts to develop curriculum in
that area. The next time the department is searching
for an Americanist, a minority faculty candidate with
an interest in African American literature will find a
potential colleague already in place, along with stu-
dents who have a grounding in the field.

McKay, Baron, and Warhol all insist that the field's scholarly value and candidates' qualifications come first. Such an approach treats seriously and respectfully both the field and candidates of color, whether or not they specialize in ethnic studies. By the same token, "making particular groups of people the targets for particular positions and relegating candidates' qualifications to a secondary role in the hiring process" (McKay, "Naming" 364) implies lesser scholarly expectations for ethnic studies fields and undermines candidates' stature as members of the faculty, as the comments quoted earlier by Smith, Cassel, Gregory, and Banks and Jewell illustrate. When departments do or appear to hire on the basis of ethnicity rather than scholarly credentials, they impose on new faculty members of color the burden of their colleagues' suspicion that they do not belong. In fact, a general atmosphere of such suspicion appears to reign, finding expression in rumor and in such articles as "The Other Candidate," in which the pseudonymous Ben Jackson wonders whether he was not hired because he was white while the other candidate was black. Without actually stating it, Jackson implies that the other candidate was 
less qualified. In order to ensure respect for ethnic studies and new faculty members of color, departments have a responsibility to job applicants; to new hires; and, when they have them, to their own graduate students to make clear that they base hiring decisions on scholarly credentials.

Despite the undersupply of black PhDs, departments are eager to increase their chances of hiring African Americans. To this end, Warhol offers several strategies in addition to hiring qualified nonblack candidates in black studies in order to build a curricular base in the department: offer incentives to job candidates of color, such as partner accommodations ranging from tuition waivers to a tenure-stream position; identify target hires through networking; talk about the institution and its location as the department would with any candidate; do not expect job candidates to take over minority student affairs; ensure that mentoring opportunities are available to new hires of color; and do not allow perfectionism to derail new hires who are ABD.

Daryl G. Smith, Caroline S. Turner, Nana Osei-Kofi, and Sandra Richards outline similar strategies in "Interrupting the Usual: Successful Strategies for Hiring Diverse Faculty." While admitting that "hiring faculty for ethnic studies departments yields the most reliable hiring of underrepresented faculty of color," they caution that such an approach

does not represent a potential intervention strategy as such unless an institution is willing to have most of its diversity located in ethnic studies programs. The potential for marginalization and restriction of scholarly range is significant enough to suggest that overreliance on these searches to secure faculty diversity is a mistake.

Noting that departments have considerable power to shape search strategies and goals, they studied which factors were associated with successful hires of candidates of color. Only 14\% of hires of African Americans followed a "regular" search. Thirtysix percent of hires of African Americans followed a job advertisement for an ethnic studies position, $27 \%$ resulted from a special hire that "bypassed normal search processes," and 23\% resulted from a special hire in an ethnic studies position (138, 142). Such data corroborate Warhol's recommendation of incentives, targeted hiring, and strong ethnic studies curricula. At the same time, depart- ments should be mindful that circumventing normal hiring practices might cast doubt on a junior faculty member's qualifications or lead the faculty member to feel tokenized.

In 2002, the MLA Committee on the Literatures of People of Color in the United States and Canada (CLPC) and the MLA Executive Council endorsed "Guidelines for Good Practice" regarding faculty members of color. Like many other authorities, the CLPC recommends the inclusion of literatures of color in specialized as well as general course work and advertisement of positions in literatures of color, in journals and newsletters devoted to literatures of color, to attract applications from candidates of color. The guidelines note the importance of senior mentors to junior faculty members and of disseminating written information on expectations for retention, tenure, and promotion. The CLPC urges departments "to be aware of the possible effects of race, gender, and sexuality bias on teaching evaluations" and to develop teaching evaluations sensitive to such effects (91). Noting that faculty members of color are called on more often than majority members to perform institutional service, the CLPC underscores the importance of protecting junior faculty members from excessive service burdens - and of rewarding substantial service when it occurs. Remarking that literatures of color may be unfamiliar to minority scholars' colleagues, the CLPC recommends giving junior faculty members of color upper-division courses in their areas, assigning new course preparations in the same ratio as other junior professors, and seeking reviewers with expertise in the faculty member's area. The CLPC envisioned the guidelines not only as a policy statement but also as a brochure to be distributed to administrators to raise their awareness of the special conditions confronting junior faculty members of color, especially at critical moments of retention, tenure, and promotion. ${ }^{1}$

The CLPC guidelines point to the importance of departmental and administrative awareness of the particular conditions of working as a faculty member of color. Similarly, Charles H. Tucker calls attention to the potentially transformative role that black administrators can play in the dynamics of departmental life, including graduate study and faculty hiring. Tucker warns against a black administrator's becoming "the sole keeper of minority affairs" and also against the administrator's "abandon[ing] his or her minority group 
status" (315). Instead, the black administrator should be to black students "a combination politician, social director, ombudsman, and problem solver" and should represent to white students "a change of mood in the institution” $(316,317)$. To these responsibilities let us add the special role that a senior black administrator can play in establishing the credibility of curricula in ethnic studies, instituting proactive hiring programs, protecting junior faculty members of color from undue service burdens, and ensuring that standards of promotion and tenure are clearly explained in writing and equitably applied.

At the level of the institution as a whole, the continuing importance of HBCUs cannot be discounted. As Historically Black Colleges and Universities from the National Center for Education Statistics shows, HBCUs play a disproportionately important role in the education of African Americans and thus in the education of African Americans who ultimately attain PhDs in English (Provasnik, Shafer, and Snyder). Not surprisingly, the proportion of African American members of the faculty is much higher at HBCUs $(58.9 \%$ in 2001) than at the nation's twenty-five highest ranking institutions (3.6\% in 2001) ("Racially Diverse Faculities"). Even the HBCU with the lowest percentage boasted a faculty that was $21.7 \%$ African American. In a major study of educational outcomes, How College Affects Students, Ernest T. Pascarella and Patrick T. Terenzini write:

Despite relative disadvantages in financial and educational resources, historically Black colleges and universities (HBCUs) appear to be as proficient as primarily White institutions (PWIs), if not more so, in fostering the knowledge acquisition (such as reading comprehension, mathematics, science reasoning) and general cognitive growth (such as critical thinking) of AfricanAmerican students. ... HBCUs ... provide their students small, positive benefits in both academic and social self-concepts. HBCUs also appear to provide modest advantages in the overall personal development of their students. . . African-American students at HBCUs (rather than PWIs) gain small to modest advantages in persistence and degree attainment. ... [Such] effects appear to be largely indirect, a function of HBCUs' more supportive faculty and peer relations and more supportive overall educational environment. ... Historically Black colleges appear to enhance the career aspirations of African-American students, and some evidence suggests that a bachelor's degree from an HBCU is linked with one dimension of career eminence among African-American women.

(597-98)
Notably, these effects suggest that lower rates of persistence at historically white institutions result in part from less supportive faculty and peer relations and less supportive overall educational environments. They also suggest that departments wishing to recruit African American graduate students would do well to look to English departments at HBCUs.

\section{The Current Legal Landscape}

Two 2003 Supreme Court decisions involving the University of Michigan, Gratz v. Bollinger and Grutter v. Bollinger, altered the permissible parameters of programs geared toward underrepresented populations. Articles by Peter Schmidt ("As Colleges Open" and "New Route") and Katherine S. Mangan, among many others, reported the varied reactions of higher education institutions as they eliminated affirmative action programs or opened them to include Asian American students, firstgeneration college students, economically disadvantaged students, or all students. In "How to Diversify Faculty: The Current Legal Landscape," Ann D. Springer, associate counsel for the American Association of University Professors, observes, "Although the Michigan cases ... do not deal directly with the issue of diversity in faculty employment, ... it is important both to understand the law (what it covers and what it does not) and the available options." According to Springer, the law on efforts to diversify the faculty "is essentially circular":

To put it simply, the Constitution and federal statutes require that employers eliminate discrimination on the basis of race or sex. Employers can be sued under these statutes both for individual discrimination ("disparate treatment" of an individual) or for policies and practices that create widespread disparities in the number of women and minorities in the workplace (actions that have a "disparate impact" on minorities as a whole).

Springer outlines the law involved, explains the legal definition of affirmative action and the reasoning in the Michigan cases, and offers numerous guidelines for effectively and legally diversifying the faculty: use broad definitions of diversity that go beyond race, gender, and national origin; consider faculty members on individual merit, using race only as a narrowly defined plus factor, not a determining factor; consider means of diversifying other than race, such as research agendas, educational ra- 
tionales, and curricular programs; treat affirmative action programs as a temporary measure to redress specific past discrimination; tie special funding to educational goals; consider not tying special funding to the hiring process itself; do not use quotas; phrase policies in terms of guaranteeing everyone an equal chance; address policies to all stages of recruitment, hiring, retention, and promotion; take aggressive action to increase the number of minority applicants, thereby increasing the chances of hiring one; take care to avoid the perception that minority faculty members were not hired based on merit; advertise in minority-serving publications and institutions; write job advertisements carefully so that they include minority candidates and do not set rigid, narrowing criteria; hire according to the terms of the job advertisement; consider adjunct and part-time faculty members, since minorities and women are overrepresented among them; brief search committees on appropriate search techniques and the institution's diversity commitment; choose search committee members carefully, privileging those with active research agendas and national exposure and those who represent the institution's diversity; provide institutional support to search committees to ease the extra burden that locating a diverse pool of candidates requires; encourage search committees to question the ways they evaluate criteria such as the prestige of graduate schools; ensure good mentoring for new hires; and ensure that tenure and promotion guidelines do not subtly discriminate by devaluing certain areas of study and service commitments, by failing to recognize the role that race can play in student evaluations, or by promoting homogeneity through collegiality criteria. Springer's recommendations could serve as a sweeping summary of the scholarship on efforts to improve the status of faculty members of color.

\section{Note}

1. Free copies of the guidelines are available in brochure form by writing the ADE at 26 Broadway, 3rd floor, New York, NY 10004. The guidelines are also available online at www.mla.org/rep_guidelines_poc.

\section{Works Cited and Consulted}

Adelman, Clifford. "Diversity: Walk the Walk, and Drop the Talk." Change Jul.-Aug. 1997: 34-45.
The Toolbox Revisited: Paths to Degree Completions from High School through College. Washington. US Dept. of Educ. 2006. 21 Feb. 2006 <http://www.ed.gov/rschstat/ research/pubs/toolboxrevisit/index.html>.

Allen, Walter R., Edgar G. Epps, Elizabeth A. Guillory, Susan A. Suh, and Marguerite Bonous-Hammarth. "The Black Academic: Faculty Status among African Americans in U.S. Higher Education." Journal of Negro Education 69.1-2 (2001): 112-27.

Anderson, Kristen J., and Gabriel Smith. "Students' Preconceptions of Professors: Benefits and Barriers according to Ethnicity and Gender." Hispanic Journal of Behavioral Sciences 27.2 (2005): 184-201.

Antonio, Anthony Lising. "Diverse Bodies, Diverse Faculties." Academe Nov.-Dec. 2003. 24 Aug. 2005 <http:// www.aaup.org/publications/Academe/2003/03nd/ 03ndanto.htm>.

Banks, William M., and Joseph Jewell. "Intellectuals and the Persisting Significance of Race." Journal of Negro Education 64.1 (1995): 75-86.

Baron, Dennis. "A Diverse Department." Chronicle of Higher Education 13 Aug. 2004: C2.

Benjamin, Lois, ed. Black Women in the Academy: Promises and Perils. Gainesville: UP of Florida, 1997.

"Black Historians Who Don't Concentrate in the Field of African-American History." Journal of Blacks in Higher Education 16 (1997): 41.

Bonner, Fred A., II. "Black Professors: On the Track but out of the Loop." Chronicle of Higher Education 11 June 2004: B11.

Butner, Bonita K., Hansel Burley, and Aretha F. Marbley. "Coping with the Unexpected: Black Faculty at Predominantly White Institutions." Journal of Black Studies 30 (2000): 453-62.

Cassel, Susie Lan. "Pitfalls in Protocols: The Persistence of Race in the Interview Process." Profession 1997. New York: MLA, 1997. 222-31.

Cole, Stephen, and Elinor Barber, with Melissa Bolyard and Annulla Linders. Increasing Faculty Diversity: The Occupational Choices of High-Achieving Minority Students. Cambridge: Harvard UP, 2003.

Committee on the Literatures of People of Color in the United States and Canada. "Guidelines for Good Practice." ADE Bulletin 132 (2002): 90-92.

Evans, Art, and Annette M. Evans. "Black Educators before and after 1960." Phylon 43.3 (1982): 254-61.

Fogg, Piper. "So Many Committees, So Little Time." Chronicle of Higher Education 19 Dec. 2003: A14.

"Fostering Graduate Diversity: A Roundtable." ADE Bulletin 128 (2001): 32-38.

Gregory, April. "Black and Female in the Academy." Chronicle of Higher Education 6 June 2003: C5.

Gregory, Sheila T. "Changing the Rules of the Game." Black Women in the Academy: The Secrets to Success and Achievement. Rev. ed. Lanham: UP of Amer., 1999. 97-107.

Harlow, Roxanna. “'Race Doesn't Matter, But . . .': The Effect of Race on Professors' Experiences and Emotion Management in the Undergraduate College Classroom." Social Psychology Quarterly 66 (2003): 348-63.

Harris, Trudier. "Black Nerds." Harris, Summer Snow 98-105. 
. "The Staying Power of Racism." Harris, Summer Snow 148-62.

- Summer Snow: Reflections from a Black Daughter of the South. Boston: Beacon, 2003.

Harvey, William B., and Eugene L. Anderson. Minorities in Higher Education: Twenty-First Annual Report, 20032004. Washington: Amer. Council on Educ., 2005.

Hendrix, Katherine Grace. "Student Perceptions of the Influence of Race on Professor Credibility." Journal of Black Studies 28 (1998): 738-63.

Hubbard, Dolan. "Democratizing the Academy: The Black Professoriat in the Twenty-First Century." ADE Bulletin 130 (2002): 13-16.

Jackson, Ben. "The Other Candidate." Chronicle of Higher Education 4 July 2003: C3.

Jackson, Jerlando F. L., and James L. Moore III. "African American Males in Education: Endangered or Ignored?" Teachers College Record 108 (2006): 201-05.

Jacobson, Jennifer. "Opening the Door to a Doctorate." Chronicle of Higher Education 13 Aug. 2004: A8.

Locke, Mamie E. "Striking the Delicate Balances: The Future of African American Women in the Academy." Benjamin 340-46.

Maguire, John. "Reversing the Recent Decline in Minority Participation in Higher Education." Minorities in Higher Education. Washington: Amer. Assn. of State Colleges and Universities, 1988. 21-41.

Mangan, Katherine S. "Bar Association Moves to Strengthen Diversity Requirements for Accreditation of Law Schools." Chronicle of Higher Education 14 Feb. 2006. 24 May 2006 <http://chronicle.com/daily/2006/ 02/2006021401n.htm>.

McKay, Nellie Y. "Naming the Problem That Led to the Question 'Who Shall Teach African American Literature?'; or, Are We Ready to Disband the Wheatley Court?” PMLA 113 (1998): 359-69.

" "A Troubled Peace: Black Women in the Halls of the White Academy." Benjamin 11-22.

Mickelson, Roslyn Arlin, and Melvin L. Oliver. "The Demographic Fallacy of the Black Academic: Does Quality Rise to the Top?" College in Black and White: African American Students in Predominantly White and in Historically Black Public Universities. Ed. Walter R. Allen, Edgar G. Epps, and Nesha Z. Hanniff. Albany: State U of New York P, 1991. 177-95.

Moody, JoAnn. Faculty Diversity: Problems and Strategies. New York: Routledge-Falmer, 2004.

-. "Supporting Women and Minority Faculty." Academe Jan.-Feb. 2004. 24 Aug. 2005 <http://www.aaup .org/publications/Academe/2004/04jf/04jfmood.htm>.

Moore, William, Jr., and Lonnie H. Wagstaff. Black Educators in White Colleges. San Francisco: Jossey-Bass, 1974.

Ochsner, Robert. "A New Chair's Perspectives, White and Black, of English Studies." ADE Bulletin 130 (2002): 17-24.

Pascarella, Ernest T., and Patrick T. Terenzini. How College Affects Students: A Third Decade of Research. San Francisco: Jossey-Bass, 2005.

Provasnik, Stephen, Linda L. Shafer, and Thomas D. Snyder. Historically Black Colleges and Universities, 1976-2001.
Natl. Center for Educ. Statistics. Sept. 2004. 31 Aug. 2005 <http://nces.ed.gov/pubs2004/2004062.pdf>.

"The Racially Diverse Faculties at America's Black Colleges." Journal of Blacks in Higher Education 45 (2004): 76.

Schmidt, Peter. "As Colleges Open Race-Exclusive Programs to All, Some Minority Students May Be Left Out in the Cold." Chronicle of Higher Education 26 Jan. 2006. 24 May 2006 <http://chronicle.com/daily/2006/ 01/2006012601n.htm>.

-. "A New Route to Racial Diversity." Chronicle of Higher Education 28 Jan. 2005 <http://chronicle.com/ weekly/v51/i21/21a02201.htm>.

Smith, Daryl G., Caroline S. Turner, Nana Osei-Kofi, and Sandra Richards. "Interrupting the Usual: Successful Strategies for Hiring Diverse Faculty." Journal of Higher Education 75.2 (2004): 133-60.

Smith, Rochelle. "Walking on Eggshells: The Experience of a Black Woman Professor." ADE Bulletin 122 (1999): 68-72.

Spillers, Hortense J. "The Crisis of the Negro Intellectual: A Post-Date.” Boundary 221 (1994): 65-116.

Springer, Ann D. How to Diversify Faculty: The Current Legal Landscape. Amer. Assn. of University Professors. Jul. 2004. 23 Feb. 2006 <http://www.aaup.org/Legal/ info\%20outlines/legaa.htm>.

Steele, Claude M. "A Threat in the Air: How Stereotypes Shape Intellectual Identity and Performance." American Psychologist 52 (1997): 613-29.

Taylor, Edward, and James Soto Antony. "Stereotype Threat Reduction and Wise Schooling: Towards the Successful Socialization of African American Doctoral Students in Education." Journal of Negro Education 69.3 (2000): 184-98.

Thompson, Carolyn J., and Eric L. Dey. "Pushed to the Margins: Sources of Stress for African American College and University Faculty." Journal of Higher Education 69.3 (1998): 324-45.

Tucker, Charles H. "The Cycle, Dilemma, and Expectations of the Black Administrator." Journal of Black Studies 10 (1980): 311-21.

Turner, Caroline Sotello Viernes, Samuel L. Myers, Jr., and John W. Creswell. "Exploring Underrepresentation: The Case of Faculty of Color in the Midwest." Journal of Higher Education 70.1 (1999): 27-59.

Warhol, Robyn. "Recruiting and Retaining Minority Faculty Members in English at the University of Vermont." ADE Bulletin 137 (2005): 57-59.

Warner, Anne Bradford. "Recruiting and Retaining African American Graduate Students.” ADE Bulletin 128 (2001): 39-40.

WebCASPAR: Integrated Science and Engineering Resources Data System. US Natl. Science Foundation. 6 Jan. 2005 <http://caspar.nsf.gov>.

West, Cornel. "The Dilemma of the Black Intellectual." Cultural Critique 1 (1985): 109-24.

Woodrow Wilson National Fellowship Foundation. Diversity and the Ph.D.: A Review of Efforts to Broaden Race and Ethnicity in U.S. Doctoral Education. May 2005. 24 Aug. 2005 <http://www.woodrow.org/newsroom/News_ Releases/WW_Diversity_PhD_web.pdf>. 